\title{
PENGEMBANGAN MULTIMEDIA INTERAKTIF PADA MATA PELAJARAN SKI UNTUK MENINGKATKAN MOTIVASI BELAJAR SISWA DI PERGURUAN THAWALIB PUTRI PADANG PANJANG \\ Depki Enanda \\ Mahasiswa Program Pascasarjana IAIN Batusangkar \\ e-mail: depki.elnanda@yahoo.com
}

\begin{abstract}
This research started from a preliminary study that Perguruan Thawalib Putri Padang Panjang on SKI grade VIII revealed that the learning process were not interactive multimedia. This study was purposed at developing an Interactive Multimedia by using software macromedia director $m x$. This paper related to the recent research in England, Kenya, New York, Korea, Mangalore, Indiana, Taiwan, Turky and Malaysia that interactive multimedia was interesting and effective to assist teachers on delivering learning materials. This study used research and development by applying 4-D models (define, design, develop and disseminate). The data were obtained from SKI teachers and students grade VIII which consist of 34 students. The observation, interview, questionnaire, documentation and testing were used as instruments. The findings revealed that interactive multimedia by using macromedia director mx to Islamic History was successful and considered valid, practical, and effective and it increased students' learning motivation.
\end{abstract}

Keywords: Interactive Multimedia, Software Macromedia Director Mx, Islamic History, Students' Learning Motivation, Perguruan Thawalib Putri Padang Panjang

\section{PENDAHULUAN}

Penulisan jurnal ini berawal dari temuan pendahuluan yang peneliti lakukan bahwa dalam proses pembelajaran Sejarah Kebudayaan Islam di kelas VIII guru belum menggunakan media pembelajaran (media interaktif), (Hasil wawancara peneliti dengan guru mata pelajaran SKI di Perguruan Thawalib Putri Padang Panjang. Hari Senin, 9 November 2015). Media yang digunakan guru dalam proses pembelajaran hanya menggunakan white board, gambargambar yang bersifat visual.

Menurut Sujdana (2010) proses pembelajaran merupakan suatu kegiatan melaksanakan kurikulum pada suatu lembaga pendidikan untuk mempengaruhi siswa dalam mencapai tujuan pendidikan. Untuk itu siswa berinteraksi dengan lingkungan belajar yang diatur oleh guru melalui proses 
pembelajaran. Adapun dalam metodologi pengajaran ada dua aspek yang paling menonjol yaitu metode mengajar dan media pengajaran sebagai alat bantu mengajar dan juga sebagai salah satu lingkungan belajar yang diatur oleh guru.

Selanjutnya hasil wawancara dengan guru SKI mengungkapkan bahwa siswa kurang termotivasi dalam belajar disebabkan tingkat kesulitan materi pelajaran SKI yang bersifat hafalan, namun guru tidak mengoreksi proses pembelajaran yang mengabaikan media. Adapun sikap kurang termotivasi siswa diantaranya; siswa banyak diam dan hanya mendengarkan, siswa kurang aktif, siswa jenuh dengan pembelajaran menggunakan metode konventional. Alasan guru mata pelajaran SKI kenapa jarang sekali menggunakan media karena media yang tersedia di sekolah sangat minim (Hasil wawancara peneliti dengan guru mata pelajaran SKI pada hari Senin, 9 November 2015).

Selanjutnya hasil wawancara dengan Siswa kelas VIII pada hari Kamis, 26 November 2015 secara umum mengatakan bahwa pembelajaran SKI yang diajarkan oleh guru mata pelajaran SKI tidak menggunakan multimedia interaktif dalam proses pembelajaran, sehingga pembelajaran menjadi monoton dengan menyampaikan materi pelajaran menggunakan metode ceramah yang lebih dominan, meskipun ada sekali-sekali menggunakan metode pembelajaran yang lain, seperti metode diskusi, dan bermain kuis, tetapi pembelajaran tidak disertai dengan penggunaan media interaktif yang dapat menarik.

$$
\text { Asnawir dan Usman (2001) }
$$

mengungkapkan penggunaaan media pengajaran secara terintegrasi dalam proses pembelajaran sangat membantu dalam meningkatkan minat dan motivasi belajar siswa di dalam kelas karena fungsi media dalam kegiatan tersebut di samping sebagai penyaji stimulus informasi, sikap dan lainlain juga untuk meningkatkan keserasian dalam penerimaan informasi. Dalam hal tertentu media juga berfungsi untuk mengatur langkah-langkah kemajuan serta untuk memberikan umpan balik.

Menurut Ariani (2010) untuk meningkatkan kemampuan memori pengetahuan siswa meliputi: $10 \%$ dari apa yang dibaca, 20\% dari apa yang didengar, $30 \%$ dari apa yang dilihat, 50\% dari apa yang dilihat dan didengar, $80 \%$ dari apa yang disampaikan/ berbicara, dan $90 \%$ dari apa yang dikatakan dan dilakukan. Berpijak dari pendapat di atas bahwa pembelajaran dengan menggunakan media pembelajaran akan meningkatkan kemampuan belajar sebesar 50\% - 60\% dari pada tanpa mempergunakan media. 
Di samping media dapat meningkatkan motivasi belajar siswa juga dapat meningkatkan hasil belajar siswa. Namun berdasarkan data yang peneliti peroleh dari guru SKI tentang hasil UTS siswa semester II pada kelas VIII banyak nilai siswa yang tidak tuntas. Berikut data hasil belajar siswa kelas VIII.

Tabel 1. Hasil UTS Siswa kelas VIII di Perguruan Thawalib Putri Padang Panjang Diperoleh dari Guru SKI pada hari Selasa, 8 Januari 2016)

\begin{tabular}{|c|l|l|l|}
\hline No & \multicolumn{1}{|c|}{ Kelas } & \multicolumn{1}{c|}{$\%$} & \multicolumn{1}{c|}{ Keterangan } \\
\hline 1 & VIII.A & $35.29 \%$ & Tuntas \\
\hline & & $64.71 \%$ & Tidak Tuntas \\
\hline 2 & VIII.B & $29.41 \%$ & Tuntas \\
\hline & & $70.59 \%$ & Tidak Tuntas \\
\hline
\end{tabular}

Di samping meningkatkan motivasi belajar siswa media pendidikan juga dapat mempertinggi proses belajar siswa dalam pengajaran yang pada gilirannya diharapkan dapat mempertinggi hasil belajar yang dicapainya. Karena melalui media bahan pengajaran akan lebih jelas maknanya, metode mengajar akan bervariasi, siswa melakukan kegiatan belajar dengan mengamati, melakukan, mendemontrasikan dan lainlain, dan pelajaran lebih menarik perhatian siswa sehingga dapat menumbuhkan motivasi belajar (Harjanto, 2008).

Jadi hasil belajar siswa akan mengalami kesuksesan atau kegagalan jika guru kurang memperhatikan motivasi belajar siswa. Lefrancois (1994) mengungkapkan bahwa "the important to the teacher of understanding motivation and the factors that affect it can hardly be overemphasized, estimate that motivation accounts for a proportion of student achievement sufficient to be the difference between succes and failure".

Susilanan (2007) mengungkapkan bahwa salah satu strategi peningkatan kualitas pembelajaran dilakukan melalui pembelajaran berbasis pemanfaatan Information and Communication Technology (ICT) dengan bersandar pada penguasaan kompetensi. Pelaksanaan strategi tersebut dilakukan melalui; penataan kurikulum, penyusunan bahan ajar/ modul, penyusunan standar pelayanan minimal (delivery sistem), penyelenggaraan pembelajaran berbasis produksi (production based learning), dan pengembangan prosedur penilaian berbasis ICT yang bersandar pada kompetensi based assessment.

Pendekatan pembelajaran dengan pemanfaatan ICT salah satunya adalah melalui pengembangan multimedia. Multimedia adalah "...also used in an educational context to describe the mix of video and audio cassetes, printed text and handbooks which traditionally make up distance learning material". The term multimedia to be a way of presenting material (often learning material) which involves three or more of the following media within a computer environment: 1) speech or other sound, 2) drawing or diagrams, 3) animated drawings or diagrams, 4) still photograps or other images, 
5) video clips, dan 6) text, i.e the printed word (Collins, et. al. 1997). Menurut Choongjae (2014) multimedia interaktif adalah “...the use of content forms that include a combination of text, audio, still image, animation, video, and described as electronic media devices, that area used to store and experiment multimedia content".

Hal yang perlu dilakukan pada saat perancangan sistem pengajaran berbasis multimedia, beberapa tahapan analisis, terutama adalah analisis terhadap frontend analysis yang menurut Lee dan Owens (2004) adalah sebagai berikut 1) audience analysis, 2) technology analysis, 3) situasion analysis, 4) Task analysis, 5) critical insident analysis, 6) objective analysis, 7) issue analysis, 8) media analysis, 9) extand data analysis, 10) cost benefit analysis.

Susilana (2007) multimedia interaktif sebagai bahan ajar bertujuan untuk: 1) memperjelas dan mempermudah penyajian pesan agar tidak terlalu verbalistis., 2) mengatasi keterbatasan waktu, ruang, dan indera peserta didik, dan 3) dapat digunakan secara tepat dan bervariasi, seperti meningkatnya gairah dan motivasi belajar siswa untuk menguasai materi secara utuh, mengembangkan kemampuan siswa dalam berinterkasi langsung dengan lingkungan dan sumber belajar lainnya terutama bahan ajar yang berbasis ICT.
Multimedia interaktif dengan menggunakan software macromedia director $m x$ ini dibuat pada mata pelajaran Sejarah Kebudayaan Islam. Macromedia director merupakan software authoring multimedia yang sangat powerfull yang bisa digunakan, baik pada sistem operasi Windows maupun Mancintosh, yang dalam hal ini berarti cross platform (Sutoyo dan Sunardi, 2005).

Zuhairini (1986) mengatakan bahwa: "Sesungguhnya pengetahuan tarikh itu banyak gunanya, baik bagi urusan keduniaan maupun bagi urusan keakhiratan". Siapa hafal (mengerti benar) tentang tarikh, bertambahlah akal pikirannya. Tarikh itu bagi masa menjadi cermin. Sesungguhnya tarikh itu menjadi cermin perbandingan bagi masa yang baru dan ilmu tarikh itu pokok kemajuan suatu umat, manakala ada suatu umat tidak memperhatikan tarikh dan ilmu tarikh, maka umat itu tentulah akan ketinggalan di belakang, dan manakala suatu umat sungguh-sungguh memperhatikan tarikh dan ilmu tarikh, maka tentulah umat itu maju ke depan.

Guru sebagai fasilitator dan motivator dalam proses pembelajaran hendaklah mencarikan solusi agar proses pembelajaran dapat berjalan dengan baik dan tercapainya tujuan pembelajaran yang diinginkan. Di samping metode yang bervariasi disampaikan oleh guru tentu proses pembelajaran akan 
menarik jika guru mampu mendesain media interaktif dalam pembelajaran. Karena media akan sangat membantu guru dalam menyampaikan informasi pembelajaran kepada siswa secara baik, menarik, dan menyenangkan. Bagi siswa tentu hal tersebut sesuatu yang berbeda, biasanya guru hanya menyampaikan pembelajaran masih bersifat konventional. Dengan adanya media interaktif akan dapat meningkatkan motivasi belajar siswa dalam pembelajaran.

Kajian multimedia interaktif ini ditemukan di beberapa Negara, seperti di Malaysia oleh Musthafa, Azlina. Najid, Norazura Ezuana Mohd. Siti Salwa Md. Sawari menyimpulkan "the uses of Prezi presentation is easy and its technique for developing a more creative and innovative approach in teaching strategies among Islamic educators".

Temuan Ayoti et. al. (2013) di Kenya mengungkapkan bahwa "the study revealed that teachers face several challenges in preparation and use of instructional media resources in teaching Kiswahili. It was concluded that there are various forms of instructional media resources that can be used in teaching various areas of Kiswahili Curriculum though there are challenges that need to be addressed to enhance the use of these resources in teaching Kiswabili".

Temuan selanjutnya masih di Malaysia oleh Ziden, Azidah Abu. Rahman,
Muhammad Faizal Abdul (2013) mengungkapkan "This study found that the application of multimedia web simulation in teaching pilgrimage topic has given positive impact on student achievements". Temuan di Padang yang ditulis oleh Adri, Muhammad dan Azhar, Nelda (2008) mengungkapkan hasil temuannya bahwa E-Media Fisika Terapan dapat meningkatkan kemampuan belajar mandiri mahasiswa, sehingga memberikan keluwesan dan kebebasan bagi mahasiswa dalam mengeksplorasi kemampuannya secara mandiri.

\section{METODE PENELITIAN}

Penelitian ini menggunakan jenis penelitian dan pengembangan (research and development). Emzir (2007) menjelaskan bahwa tujuan utama penelitian dan pengembangan ini bukanlah untuk menguji atau merumuskan teori, tetapi untuk mengembangkan produk-produk yang efektif untuk digunakan di sekolahsekolah. Sugiyono (2007) mendefinisikan penelitian dan pengembangan adalah metode penelitian yang digunakan untuk menghasilkan produk tertentu, dan menguji keefektifan produk tersebut. Berkenaan dengan produk, telah dikembangkan berbagai produk misalnya bahan ajar, modul, bahan ajar bergambar, bahan ajar interaktif, bahan ajar online; dibidang 
media pembelajaran, contohnya media interaktif atau multimedia interaktif, media gambar seri dan seterusnya (Setyosari, 2015). Lebih lanjut Setyosari (2015) mendefinisikan R \& D sebagai “...as apposed to simple inteructional development, has been defined as the systematic study is designing, developing and evaluating instructional programs, processes and products that must meet the criteria of internal consistency and effectiveness".

Metode penelitian dan pengembangan yang digunakan dalam penelitian ini dilakukan dengan dua pendekatan, yaitu pendekatan kualitatif dan pendekatan kuantitatif. Intrumen penelitian yang digunakan dalam penelitian dan pengembangan ini yaitu berupa observasi, wawancara, angket, tes dan dokumentasi.

Menurut Hanafi (2014) observasi merupakan yang akan mengamati tentang dokumen yang berkaitan dengan masalah, seperti silabus, buku ajar, hasil belajar siswa, media, metode yang digunakan guru dan sebagainya. Selanjutnya Marshall (1995) menyatakan bahwa "through observation, the researcher learn about behavior and the meaning attached to those behavior.

Wawancara akan menggali data yang berbentuk ucapan, tindakan, setting dari sasaran klien yang representatif untuk diwawancarai dengan menggunakan pedoman wawancara, buku catatan, tape recorder. Angket (questionnaire) akan menggali data yang ada pada subjek penelitian yang menjadi sasaran klien, dan pakar untuk menilai hasil produk akhir (Hanafi, 2014). Instrumen angket dalam penelitian ini bentuk tertutup dan skala bertingkat (skala likert).

Metode dokumentasi merupakan suatu cara pengumpulan data yang menghasilkan catatan penting yang berhubungan dengan masalah yang diteliti (Basrowi, 2008). Tes adalah alat pengukur atau teknik, cara dalam rangka melaksanakan kegiatan evaluasi, yang didalamnya terdapat berbagai item atau serangkaian tugas, perintah, pertanyaanpertanyaan yang harus dijawab, dikerjakan oleh peserta didik. Kemudian dengan jawaban dan pekerjaan itu menghasilkan nilai tentang perilaku peserta didik tersebut (Ilyas, 2006). Selanjutnya sumber data diperoleh dari 2 orang guru mata pelajaran SKI. Dan sumber data kedua di peroleh dari siswa kelas VIII sebanyak 34 orang siswa, yaitu melalui instrumen angket respon siswa yang diberikan kepada siswa.

Model pengembangan penelitian yang digunakan dalam penelitian ini adalah model pengembangan 4-D. Model pengembangan ini terdiri atas empat tahap pengembangan yaitu, tahap pendefenisian (define), tahap perancangan (design), tahap pengembangan 
(develop), dan tahap penyebarluasan (disseminate) (Trianto, 2009). Berikut rancangan penelitian terdapat pada bagan di bawah ini.

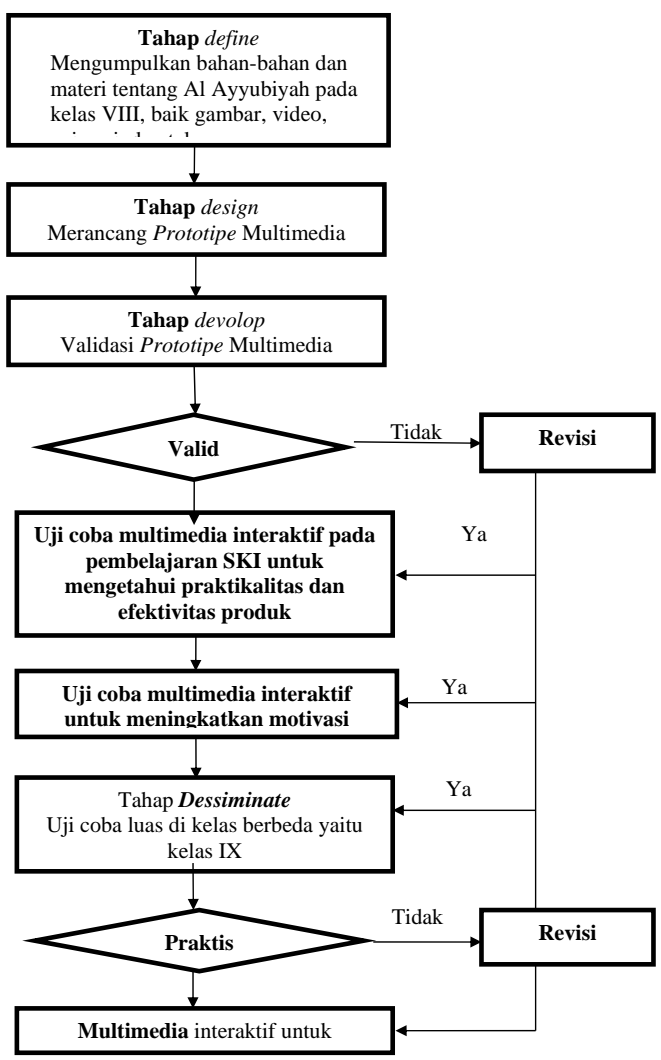

Gambar 1. Prosedur Penelitian

Berikut penjelasan hasil prosedur penelitian dan pengembangan yang telah dilaksanakan.

\section{Tahap Pendefinisian (Define).}

Tahap ini bertujuan untuk menemukan dan mengumpulkan seluruh bahanbahan yang terkait dengan materi $\mathrm{Al}$ Ayyubiyah yang akan dibuat menjadi multimedia pembelajaran interaktif.

\section{Tahap Perencanaan (Design)}

Tahap design bertujuan untuk merancang prototipe multimedia menggunakan sofware macromedia director $m x$ pada materi Dinasti Al Ayyubiyah.

\section{Tahap Pengembangan (Develop)}

Tujuan tahap ini adalah untuk menghasilkan perangkat pembelajaran yang sudah direvisi berdasarkan masukan dari pakar dan mengetahui tingkat kepraktisan multimedia menggunakan sofware macromedia director $m x$. Tahap ini dilakukan dengan langkah-langkah uji validitas, uji praktikalitas, uji efektivitas, dan uji motivasi belajar siswa.

Tabel 2. Teknik Pengumpulan Data

\begin{tabular}{|c|l|l|l|}
\hline No & $\begin{array}{c}\text { Aspek yang } \\
\text { diteliti }\end{array}$ & $\begin{array}{c}|c| \\
\text { Peknik } \\
\text { Pengumpulan Data }\end{array}$ & Instrumen \\
\hline 1 & Validitas & $\begin{array}{l}\text { Diskusi dengan } \\
\text { Pakar IT, Pakar } \\
\text { Pendidikan SKI }\end{array}$ & $\begin{array}{l}\text { Lembar } \\
\text { validasi }\end{array}$ \\
\hline 2 & Praktikalitas & Angket respon Siswa & $\begin{array}{l}\text { Angket } \\
\text { praktikalitas }\end{array}$ \\
\hline 3 & Efektivitas & Ulangan Harian & $\begin{array}{l}\text { Uji coba tes } \\
\text { tulis }\end{array}$ \\
\hline 4 & $\begin{array}{l}\text { Motivasi } \\
\text { Belajar Siswa }\end{array}$ & $\begin{array}{l}\text { Angket Respon } \\
\text { Siswa }\end{array}$ & $\begin{array}{l}\text { Angket } \\
\text { Motivasi }\end{array}$ \\
\hline
\end{tabular}

\section{Tahap Pendiseminasian (disseminate)}

Menurut Trianto (2009) bahwa tahap ini merupakan tahap penggunaan perangkat yang telah dikembangkan pada skala yang lebih luas, misalnya di kelas lain, di sekolah lain, oleh guru yang lain. Tujuan lain adalah untuk menguji efektivitas penggunaan perangkat didalam kegiatan belajar mengajar. 
Teknik analisis data yang digunakan peneliti dalam penelitian ini adalah analisis data kuantitaif sebagaimana dijelaskan di bawah ini:

\section{a. Uji Validitas Instrumen Penelitian}

Uji validitas instrumen penelitian ini menggunakan perhitungan Korelasi Product Moment untuk mengetahui kevalitan instrumen penelitian. Maka perlu diuji signifikansinya dengan rumus korelasi Product Moment. Adapun rumusnya adalah sebagai berikut.

$R_{x y}=\frac{n\left(\sum x y\right)-\left(\sum x\right)\left(\sum y\right)}{\left(\sqrt{\left\{n\left(\sum x^{2}\right)-\left(\sum x\right)^{2}\right\}\left\{n\left(\sum y^{2}\right)-\left(\sum y\right)^{2}\right\}}\right)}$

Dimana :

$R_{x y}:$ Korelasi

$\Sigma X$ : Jumlah Skor yang diperoleh dari responden yang diuji

$\sum Y$ : Jumlah skor total seluruh item dari keseluruhan responden yang diuji

n : Jumlah responden (Sugiyono, 2007)

Biasanya syarat minimum untuk dianggap memenuhi syarat adalah kalau $r_{\text {hitung }}>r_{\text {tabel }}$ " jadi kalau korelasi antara butir dengan skor total kurang dari 0.05 maka butir dalam instrumen tersebut dinyatakan tidak valid. Kemudian peneliti juga menganalisis hasil pengisian lembar validasi pelaksanaan multimedia interaktif menggunakan software macromedia director $m x$ yang diolah secara statistik dengan teknik tabulasi dengan menentukan skor total, skor rata-rata, skor ideal dan presentase tingkat pencapaian responden.

Tingkat pencapaian $=\coprod$ umlah Keseluruhan X 100\% Jumlah Maximal

\section{b. Reliabilitas Instrumen Penelitian}

Reliabilitas merupakan alat untuk mengukur suatu kuesioner yang merupakan indikator dari variabel. Suatu kuesioner dikatakan reliabel atau handal jika jawaban seseorang terhadap pernyataan konsisten atau stabil dari waktu ke waktu. Uji reliabilitas instrumen penelitian dilakukan dengan menggunakan program SPSS 16 dengan komputer. Untuk mengukur reliabilitas instrumen penelitian digunakan rumus Alpha.

\section{c. Uji Hipotesis}

Uji hipotesis pada penelitian ini menggunakan rumus korelasi product moment. Bila ingin memprediksi bagaimana pengaruh variabel independen terhadap variabel dependen maka dianalisis

$R_{x y}=\frac{n\left(\sum x_{i} y_{i}\right)-\left(\sum x_{i}\right)\left(\sum y_{i}\right)}{\left(\sqrt{\left\{n\left(\sum x_{i}^{2}\right)-\left(\sum x_{i}\right)^{2}\right\}\left\{n\left(\sum y_{i}^{2}\right)-\left(\sum y_{i}\right)^{2}\right\}}\right)}$

Untuk uji signifikan variabel, maka uji hipotesisnya adalah. 


\begin{tabular}{|l|l|}
\hline $\begin{array}{l}\text { Jika rhitung }> \\
\text { rtabel }\end{array}$ & $\begin{array}{l}\text { Ha: Diterima } \\
\text { Maka terdapat hubungan yang } \\
\text { signifikan antara multimedia } \\
\text { interaktif dengan motivasi belajar } \\
\text { siswa. }\end{array}$ \\
\hline $\begin{array}{l}\text { Jika rhitung } \\
<\text { rtabel }\end{array}$ & $\begin{array}{l}\text { Ho: Ditolak } \\
\text { Maka tidak terdapat hubungan } \\
\text { yang signifikan antara multimedia } \\
\text { interaktif dengan motivasi belajar } \\
\text { siswa. }\end{array}$ \\
\hline
\end{tabular}

d. Uji T

Selanjutnya menganalisis hasil pengisian kuesioner terhadap pelaksanaan multimedia interaktif menggunakan software macromedia director $m x$ akan dianalisis dengan menggunakan Program SPSS versi 16. Analisis tersebut dilakukan dengan uji statistik t-test dengan independent sample t-test. Independent sample t-test yaitu uji statistik yang digunakan untuk menganalisis data numerik, dilakukan pada subjek yang berbeda terhadap suatu pengaruh atau satu perlakuan. T-test dilakukan untuk mengetahui efektivitas multimedia interaktif terhadap peningkatan hasil belajar siswa. Masing-masing data sebelum dan sesudah diperbandingkan dengan melihat perbedaan thitung dengan $\mathrm{t}$ tabel dan $P$ Value dengan a (0,01 dan 0,05). Apakah hasil belajar siswa yang menggunakan multimedia interaktif meningkat setelah menggunakan multimedia interaktif dalam proses pembelajaran dibandingkan dengan hasil belajar siswa yang tanpa menggunakan multimedia interaktif?

\section{HASIL PENGEMBANGAN DAN PEMBAHASAN}

Berdasarkan penelitian pengembangan yang telah dilakukan di lapangan bahwa pengembangan multimedia interaktif menggunakan software macromedia director $m x$ ini adalah model pengembangan 4-D. Model pengembangan 4-D terdiri atas empat tahap pengembangan, yaitu: tahap define (pendefinisisan), tahap design (perancangan), tahap develop (pengembangan), dan tahap disseminate (penyebarluasan).

\section{Analisis Define (Pendefenisian)}

Pada tahap define (pendefinisian) dilakukan analisis kebutuhan guru, analisis kebutuhan siswa terhadap multimedia interaktif, analisis kebutuhan, Silabus. Dalam analisis kebutuhan ini, peneliti melakuakn need analysis, Contextual analysis, dan theory analysis. Dari data yang ditemukan di lapangan dengan melakukan wawancara kepada guru SKI dan siswi kelas VIII di Perguruan Thawalib Putri Padang Panjang. Adapun hasil wawancara terdapat pada tabel di bawah ini. 
Tabel 3. Hasil Wawancara Analisis Kebutuhan (Need Analysis) Guru SKI Pada Hari Selasa, 10 November 2015

\begin{tabular}{|c|l|}
\hline No & \multicolumn{1}{|c|}{ Data Temuan Secara Umum } \\
\hline 1 & $\begin{array}{l}\text { Berdasarkan hasil wawancara analisis kebutuhan (needs } \\
\text { analisis) guru mata pelajaran SKI dapat disimpulkan } \\
\text { bahwa guru sangat butuh dengan pembelajaran } \\
\text { menggunakan multimedia interaktif }\end{array}$ \\
\hline 2 & $\begin{array}{l}\text { Multimedia interaktif sangat penting digunakan } \\
\text { dalam proses pembelajaran untuk dapat membantu } \\
\text { guru menyampaikan materi pembelajaran dengan } \\
\text { menggunakan multimedia interaktif yang menarik, } \\
\text { menyenangkan dan efektif }\end{array}$ \\
\hline
\end{tabular}

Selanjutnya hasil wawancara dengan siswa kelas VIII terhadap need analysis (analisis kebutuhan) siswa terdapat pada tabel di bawah ini.

Tabel 4. Hasil Wawancara Analisis Kebutuhan (Need Analysis) Siswa Pada Hari Kamis, 26 November 2015

\begin{tabular}{|c|l|}
\hline No & \multicolumn{1}{|c|}{ Data Temuan Secara Umum } \\
\hline 1 & $\begin{array}{l}\text { Berdasarkan hasil wawancara peneliti dengan siswa kelas VIII } \\
\text { tentang kebutuhan siswa terhadap multimedia interaktif } \\
\text { dapat disimpulkan bahwa siswa sangat butuh pembelajaran } \\
\text { dengan menggunakan multimedia interaktif. Karena selama } \\
\text { ini pembelajaran masih bersifat konvensional }\end{array}$ \\
\hline 2 & $\begin{array}{l}\text { Siswa sangat tertarik dengan pembelajaran menggunakan } \\
\text { multimedia interaktif }\end{array}$ \\
\hline 3 & $\begin{array}{l}\text { Siswa sangat berharap supaya guru dan sekolah } \\
\text { mendukung melaksanakan pembelajaran dengan } \\
\text { menggunakan multimedia interaktif }\end{array}$ \\
\hline
\end{tabular}

Selanjutnya, peneliti melakukan contextual analysis yaitu tempat di mana di terapkan produk multimedia interaktif dalam proses pembelajaran pada kelas VIII untuk mengetahui efektif dan praktis tidaknya media tersebut. Dan dilakukan di kelas IX untuk mengetahui kepraktisan produk multimedia interaktif. Sekolah memiliki laboraturium, infokus, dan $\mathrm{Wi-}$ Fi (Wireless Fidelity). Berdasarkan analisis konteks dapat disimpulkan bahwa sekolah mendukung untuk diterapkan multimedia interaktif dalam proses pembelajaran di kelas.
Terakhir peneliti melakukan theory analysis yang terkait dengan multimedia bahwa Daryanto (2010: 64) mengungkapkan 1) pemanfaatan multimedia menjadi suatu solusi dalam peningkatan kualitas pembelajaran di kelas, 2) bertujuan untuk memudahkan guru menyampaikan pembelajaran yang komunikatif dan interaktif, 3) pengembangan multimedia dapat dimanfaatkan pembelajaran di kelas. Menurut Padmanthara (2007) dalam Kristiawan (2014: 88) pembelajaran dengan berbantuan komputer “...telah dikembangkan akhir-akhir ini dan telah membuktikan manfaatnya untuk membantu guru dalam mengajar dan membantu siswa dalam belajar". Komputer dapat membantu puluhan siswa sekaligus dan di masa yang akan datang diharapkan dapat membantu ribuan siswa sekaligus.

Susilanan dkk. (2007) menyebutkan bahwa multimedia interaktif sebagai bahan ajar bertujuan untuk: 1) memperjelas dan mempermudah penyajian pesan agar tidak terlalu verbalistis., 2) mengatasi keterbatasan waktu, ruang, dan indera peserta didik, dan 3) dapat digunakan secara tepat dan bervariasi, seperti meningkatnya gairah dan motivasi belajar siswa untuk menguasai materi secara utuh, mengembangkan kemampuan siswa dalam berinterkasi langsung dengan lingkungan dan sumber belajar lainnya terutama bahan ajar yang berbasis ICT. 


\section{Analisis design (perancangan)}

Tahap design dengan tujuan menghasilkan prototipe multimedia menggunakan software macromedia director $m x$. Prototipe multimedia menggunakan software macromedia director $m x$ yang dikembangkan adalah tentang Dinasti Ayyubiyah. Multimedia interaktif menggunakan software macromedia director $m x$ berisi materi-materi yang sesuai dengan indikator-indikator yang telah dianalisa sebelumnya.

Menurut Susilanan (2007), pengembangan media interaktif dapat ditempuh dengan langkah-langkah berikut yaitu: (1) pembuatan garis besar program media, (2) pembuatan flowchart, (3) pembuatan storyboard, (4) pengumpulan bahan-bahan yang dibutuhkan, (5) pemograman, (6) finishing.

\section{Analisis Develop (Pengembangan)}

Sebelum analisis develop (pengembangan) dilakukan. Produk multimedia menggunakan software macromedia director $m x$ yang telah selesai di diskusikan terlebih dahulu dengan pembimbing.

\section{a. Analisis Validitas}

Analisis validitas dilakukan adalah validasi isi (conten validity). Hal ini dilakukan dengan cara pemberian penilaian oleh validator terhadap prototipe multimedia menggunakan software macromedia director yang telah dikembangkan. Validator berjumlah 2 orang Dosen IAIN Batusangkar yaitu Dr. Muhammad Kristiawan, M.Pd. dan Dr. Suharmon, M.A.

Prototipe multimedia interaktif menggunakan software macromedia director $m x$ yang telah divalidasi kemudian didiskusikan dengan validator tentang kevalidan produk yang dikembangkan. Prototipe multimedia menggunakan software macromedia director $m x$ direvisi sesuai dengan saran validator. Setelah itu, berdiskusi kembali dengan validator. Dari hasil diskusi tersebut diperoleh prototipe multimedia menggunakan software macromedia director $m x$ yang valid.

Dari hasil validasi multimedia interaktif menggunakan software macromedia director mx yang dinilai oleh validator bahwa dapat diketahui rata-rata hasil validasi secara umum adalah 91.25 $\%$ dengan kategori sangat valid. Dari aspek-aspek yang dinilai dapat rata-rata nilai pada kriteria umum $95 \%$, kriteria khusus $100 \%$, aspek praktis $80 \%$, dan aspek teknis $90 \%$. Pengkategorian hasil validitas multimedia interaktif menggunakan software macromedia director $m x$ berdasarkan pendapat Riduwan, dimana persentase antara 
$0 \%-20 \%$ dengan kategori tidak valid, $21 \%-40 \%$ dengan kategori kurang valid, $41 \%$ - 60\% dengan kategori cukup valid, $61 \%$ - $80 \%$ dengan kategori valid, 81\%-100\% dengan kategori sangat valid.

\section{b. Hasil Analisis Validasi Rencana} Pelaksanaan Pembelajaran (RPP)

Hasil validasi RPP yang dinilai oleh validator diketahui rata-rata hasil validasi secara umum adalah $92.08 \%$ dengan kategori sangat valid. Dari aspek-aspek yang dinilai didapat rata-rata nilai pada syarat didaktik $97.5 \%$, syarat konstruk $88.75 \%$, dan syarat teknis $90 \%$. Pengkategorian hasil validitas RPP berdasarkan pendapat Riduwan, dimana persentase antara $0 \%$ - 20\% dengan kategori tidak valid, $21 \%$ $40 \%$ dengan kategori kurang valid, $41 \%$ $-60 \%$ dengan kategori cukup valid, $61 \%$ - $80 \%$ dengan kategori valid, $81 \%-100 \%$ dengan kategori sangat valid. Dari hasil validasi RPP yang telah dinilai validator menunjukan RPP yang dirancang sangat valid.

c. Hasil Analisis Praktikalitas Produk Multimedia Interaktif

1) Uji Kepraktisan

Berdasarkan hasil respon angket dari 34 orang siswa kelas VIII MTs Thawalib Putri Padang Panjang terhadap kepraktisan produk multimedia interaktif menggunakan software macromedia director $m x$ yang digunakan selama pembelajaran adalah sangat praktis dengan perolehan skor rata-rata $90.38 \%$. Hal ini berarti pada umumnya siswa memberikan apresiasi yang sangat baik dalam penggunaan multimedia interaktif menggunakan software macromedia director $m x$ ini dalam proses pembelajaran.

2) Uji Validitas Instrumen Hasil uji validitas instrumen kepraktisan produk multimedia interaktif memiliki tingkat hubungan yang sedang dengan instrumen. Adapun uji valitidas instrumen berada pada kategori cukup valid.

3) Uji Reliabilitas Instrumen Hasil uji Reliabilitas instrumen kepraktisan multimedia interaktif terdapat pada tabel di bawah ini.

\begin{tabular}{|l|l|}
\hline \multicolumn{2}{|c|}{ Tabel 5. Reliability Statistics } \\
\hline Cronbach's Alpha & N of Items \\
\hline .725 & 17 \\
\hline
\end{tabular}

Berdasarkan tabel alpha di atas, maka dapat disimpulkan bahwa kuesioner ini dikatakan reliabel atau handal jika jawaban seseorang terhadap pernyataan adalah konsisten atau stabil dari waktu ke waktu. Koefisien perolehan yaitu 0.725 maka koefisien tersebut dapat dikategorikan kuat. 


\section{d. Analisis Efektifitas}

\section{1) Analisis Data Hasil Belajar Siswa}

Berdasarkan hasil uji coba tes terhadap siswa yang dalam pembelajaran dengan menggunakan multimedia interaktif dapat disimpulkan bahwa siswa kelas VIII.A sebanyak 11 orang mendapatkan nilai tuntas dan jumlah siswa 6 orang mendapatkan nilai tidak tuntas karena KKM pada mata pelajaran SKI 70. Sedangkan pembelajaran yang dilakukan di kelas VIII.B tanpa menggunakan multimedia interaktif dapat disimpulkan bahwa sebanyak 6 orang siswa mendapatkan nilai tuntas sedangkan sebanyak 11 orang siswa yang tidak tuntas. Jadi kesimpulan secara umum pembelajaran dengan menggunakan multimedia interaktif mampu meningkatkan hasil belajar siswa dengan yang tidak menggunakan multimedia interaktif.

\section{2) Uji T}

Setelah uji hipotesis maka pengujian dilanjutkan uji signifikansi yang berfungsi untuk mencari hubungan variabel X terhadap Y maka diuji dengan uji signifikansi/ uji $\mathrm{T}$ test dengan menggunakan SPSS 16. Selanjutnya untuk melihat interpretasi pada tabel t test maka digunakan rumus. $\mathrm{db}=$ $n 1-1+n 2-1$

Tabel 6. Hasil Uji T

Independent Samples Test

\begin{tabular}{|l|l|l|l|l|l|l|l|l|l|l|}
\hline \multicolumn{2}{|c|}{} & \multicolumn{3}{|c|}{$\begin{array}{l}\text { Levene's Test for } \\
\text { Equality of Variances }\end{array}$} & \multicolumn{6}{|c|}{ t-test for Equality of Means } \\
\cline { 2 - 10 } & F & Sig. & T & Df & $\begin{array}{l}\text { Sig. } \\
(2-\text {-tailed })\end{array}$ & $\begin{array}{l}\text { Mean } \\
\text { Difference }\end{array}$ & $\begin{array}{l}\text { Std. Error } \\
\text { Difference }\end{array}$ & $\begin{array}{l}\text { 95\% Confidence } \\
\text { Interval of the } \\
\text { Difference }\end{array}$ \\
\hline Lower & Upper \\
\hline Nilai & $\begin{array}{l}\text { Equal variances } \\
\text { assumed }\end{array}$ & .041 & .841 & 3.758 & 32 & .001 & 15.29412 & 4.07010 & 7.00359 & 23.58465 \\
\hline & $\begin{array}{l}\text { Equal variances not } \\
\text { assumed }\end{array}$ & & & 3.758 & 31.637 & .001 & 15.29412 & 4.07010 & 6.99986 & 23.58838 \\
\hline
\end{tabular}

Berdasarkan tabel di atas diperoleh $t_{\text {hitung }}=3.758$ dan diperoleh $\mathrm{df}$ (degress of freedom) 32, selanjutnya dilihat dalam $t_{\text {tabel }}$ pada urutan yang 32 diperoleh pada taraf $0,1 \%=1.303$ dan pada taraf $0.5 \%$ $=1.684$. Hasil analisis t-test kelas VIII pada tabel di atas menjelaskan bahwa $t_{\text {hitung }}$ lebih besar dari $t_{\text {tabel }}$ pada taraf $1 \%$ yaitu $(3.758$ $>1.303)$ dan pada taraf $5 \%$ diperoleh $t_{\text {hitung }}>t_{\text {tabel }}$ yaitu $(3.758>1.684)$. Dari hasil tersebut dapat disimpulkan bahwa multimedia interaktif tersebut berpengaruh terhadap peningkatan hasil belajar siswa kelas VIII.

Berdasarkan hasil analisis, $t_{\text {hitung }}$ lebih besar dari $t_{\text {tabel }}$ pada taraf signifikan $1 \%$ dan $5 \%$ dengan demikian dapat dinyatakan 
Hipotesis alternatif ( $\mathrm{Ha}$ ) diterima dan Hipotesis nihil (Ho) ditolak. Sebagai hasil, maka dapat disimpulkan bahwa pada taraf $1 \%$ dan 5\% terdapat pengaruh yang signifikan antara hasil belajar siswa yang tanpa menggunakan multimedia interaktif dengan yang menggunakan multimedia interaktif.

\section{e. Analisis Hasil Motivasi Belajar Siswa}

Analisis hasil motivasi belajar siswa bertujuan untuk melihat apakah motivasi belajar siswa meningkat setelah guru menggunakan multimedia interaktif dalam proses pembelajaran. berdasarkan hasil analisis kuesioner respon siswa tentang motivasi belajar siswa dengan perolehan nilai rata-rata 86.58 maka hasil analisis angket motivasi belajar siswa berada pada kriteria sangat tinggi. Artinya setelah guru menggunakan multimedia interaktif dalam proses pembelajaran maka motivasi belajar siswa meningkat dengan sangat tinggi.

\section{Analisis Dessiminate}

Berdasarkan hasil respon angket dari 20 orang siswa kelas IX terhadap kepraktisan produk multimedia interaktif menggunakan software macromedia director $m x$ yang digunakan selama pembelajaran adalah sangat praktis dengan perolehan skor ratarata $86.85 \%$.
Temuan lapangan menyimpulkan bahwa guru belum memanfaatkan multimedia interaktif sebagai alat bantu pembelajaran. Hal tersebut merupakan bukti perlunya dihadirkan produk multimedia interaktif sebagai alat bantu pembelajaran yang dapat membantu guru memanfaatkan komputer sebagai alat bantu pembelajaran. Dari hasil penelitian dapat disimpulkan bahwa produk multimedia interaktif dalam penelitian ini valid, praktis dan efektif serta dapat meningkatkan motivasi belajar siswa.

\section{PEMBAHASAN}

Berikut ini beberapa penelitian relevan yang mendukung penelitian yang dilakukan, tentunya penelitian tersebut secara subtansial berkaitan dengan pemanfaatan multimedia dalam pembelajaran. Pertama, temuan oleh Liju James \& Shivakumara di Mangalore mengungkapkan bahwa pembelajaran dengan menggunakan multimedia “...the results of this study show that majority (62.5\%) of the students are showed mild behaviour. About 30.8\% of the students showed moderate behaviour and $6.7 \%$ of the students showed severe behavioural changes due to the influence of multimedia usage".

Kedua, temuan oleh Choongjae \& Myonghwa di Korea Selatan mengungkapkan bahwa multimedia interaktif dengan menggunakan teknologi komputer sangat 
efektif dalam pembelajaran, “...Participants receiving interactive multimedia education had significantly higher self-efficacy ( $F 1 / 420.03$, $p<.001)$ and knowledge (F 1/4 36.26, $p<$ .001) scores than the control group did at post intervention. The experimental group indicated a high degree of satisfaction with the interactive multimedia education. And the study results suggest that the interactive multimedia education is an effective teaching method that empowers older adults to facilitate individual learning using computer technology".

Ketiga, temuan oleh Melanie Firguson, Marian Brandret, William Brassingthon \& Heather Wharrad di United Kingdom (Inggris), mengungkapkan hasil penelitiannya "... knowledge of both practical and psychosocialissues was significantly higher in the group that received the Reusable Learning Objecs (RLOs) than in the control group. Moderate to large effect sizes indicated that these differences were clinically significant. Conclusion: An educational intervention that supplements clinical practice results in improved knowledge in first-time hearing aid users".

Keempat, temuan yang dilakukan oleh Theresa A. Ochoa di Indiana University Bloomington mengungkapkan bahwa "implication of using multimedia Problem Based Learning (PBL) technology and special education teacher preparation courses are discussed". Kelima, temuan oleh Ramshaw, Young,
Garsha, Shuler, Wilson, Write, Duncan and Mason (2001) di Newyork menyimpulkan bahwa "... The use of multimedia interactive training programs in addition to current laparoscopic training courses may help to increase the safe adoption of laparoscopic procedures. These programs may be a beneficial adjunct to residency training programs".

Keenam, temuan yang dilakukan oleh Chaty Newman Thomas (The University of Missouri) and Herbeht J. Rhiet (The University Texas at Austin) (2011) mengungkapkan temuan penelitiannya bahwa “...that multimedia anchored instruction is an affective servise delivery model for meeting these preservise teacher education goal".

Ketujuh, temuan Yeh, Mei-Ling. Chen, Hsing-Hsia. Yu-Chu Chung di Taiwan (2012) mengungkapkan hasil penelitian ini "... demonstrated acupressure combined with interactive multimedia had a long-term effect in the improvement of visual health and related knowledge. The interactive multimedia was evaluated as having high satisfaction. Slowing myopic progression was a greater long-term effect of visual health in acupressure combined with interactive multimedia than acupressure alone".

Kedelapan, temuan oleh Kristiawan di Padang (2014) bahwa hasil dari penelitian ini menyimpulkan bahwa perangkat lunak yang memuat pemanfaatan komputer dengan menggunakan aplikasi Microsoft 
Word 2007; Microsoft Excel 2007; Microsoft PowerPoint 2007; Email: Facebook; Blogging; Quiz Creator; Adobe Photoshop; Adobe Flash; dan Youtube dinyatakan valid, praktis dan efektif. Kesimpulan dari penelitian ini sesuai dengan kebutuhan guru maupun kebijakan pendidikan di Indonesia. Penelitian ini berdampak tidak hanya mengintegrasikan komputer pada kurikulum, tetapi bagaimana memastikan guru memiliki kemampuan TIK dalam pengajaran.

Kesembilan, temuan oleh Adri (2008) di Padang mengungkapkan "Pengembangan multimedia instructional, jauh lebih kompleks jika dibandingkan dengan model tradisional. Karena misi pembelajaran harus tetap menjadi focus utama pengembangan, selain pemilihan teknologi dan tujuan pengembangan lainnya. Bahwa strategi pengembangan Multimedia Intructional Design yang dikembangkan dapat menjadikan pembelajaran yang menarik dan digunakan oleh mahasiswa dengan mudah.

Kesepuluh, temuan oleh Purwitasari, dengan judul "Pengembangan Media Pembelajaran Interaktif Pendidikan Agama Islam Menggunakan Adobe Flash Professional CS pada Materi Perilaku Dendam dan Munafik Kelas VIII di SMP Negeri Baturetno Wonogiri" bahwa media yang dibuatnya memiliki persentasi kelayakkan 88\% dengan interpretasi sangat layak.
Kesebelas, temuan oleh Mahsunah (2011) mengungkapkan bahwa hasil penelitian menunjukkan bahwa seluruh aspek dalam produk pembelajaran ini secara umum mendapat tanggapan yang baik dari ahli materi, media, dan dari peserta didik sebagai pengguna (user). Selanjutnya temuan kedua belas oleh Uslu \& Bumen (2012) di Turki menyimpulkan bahwa "there is a positive effect of the professional development (PD) program on technology integration (TI) besides attitudes towards ICT in education of Turkish teachers".

\section{KESIMPULAN}

Hasil validitas multimedia interaktif menggunakan software macromedia director $m x$ pada mata pelajaran SKI dengan materi Dinasti Ayyubiyah di kelas VIII MTs Thawalib Putri Padang Panjang yang dinilai oleh validator dinyatakan sangat valid, dengan rata-rata hasil validasi secara umum diperoleh $91.25 \%$. Adapun hasil praktikalitas produk multimedia interaktif dinyatakan sangat praktis dari segi keterbacaan dengan perolehan skor rata-rata $90.38 \%$. Dan uji reliabilitas instrumen multimedia interaktif memperoleh koefisien yaitu 0.725 maka koefisien kategori reliabilitasnya pada kategori kuat.

Selanjutnya hasil efektivitas produk multimedia interaktif diperoleh hasil analisis $t_{\text {hitung }}$ lebih besar dari $t_{\text {tabel }}$ pada taraf $1 \%$ yaitu $(3.758>1.303)$ dan pada taraf $5 \%$ 
diperoleh $t_{\text {hitung }}>t_{\text {tabel }}$ yaitu $(3.758>$ 1.684). Pada taraf signifikan $1 \%$ dan $5 \%$ dengan demikian dapat dinyatakan Hipotesis alternatif (Ha) diterima dan Hipotesis nihil (Ho) ditolak. Sebagai hasil, maka dapat disimpulkan bahwa pada taraf $1 \%$ dan $5 \%$ terdapat pengaruh yang signifikan antara hasil belajar siswa yang menggunakan multimedia interaktif dengan yang tanpa menggunakan multimedia interaktif. Artinya hasil produk multimedia interaktif efektif untuk digunakan dalam proses pembelajaran.

Selanjutnya hasil uji motivasi belajar siswa dengan menggunakan kuesioner respon siswa tentang motivasi belajar siswa memperoleh nilai rata-rata 86.58 maka hasil analisis angket motivasi belajar siswa berada pada kriteria sangat tinggi. Artinya setelah guru menggunakan multimedia interaktif dalam proses pembelajaran maka motivasi belajar siswa meningkat dengan sangat tinggi.

\section{KEPUSTAKAAN ACUAN}

Adri, Muhammad dan Azhar, Nelda (2008). "Pengembangan Paket Multimedia Interaktif sebagai Sarana Belajar Mandiri Mahasiswa". Komunitas eLearning IlmuKomputer.Com. Copyright (C) 20032008 IlmuKomputer. Com.

Adri, Muhammad (2008). "Strategi Pengembangan Multimedia Instructional
Design”. Komunitas eLearning IlmuKomputer.Com. Copyright (C) 20032008 IlmuKomputer. Com.

Alhidayah (2010) Al-Qur'an Tafsir Per kata Tajwid Kode Angka. Jakarta: Kalim.

Ariani, Niken \& Haryanto, Dany (2010). Pembelajaran Multimedia di Sekolah, Pedoman Pembelajaran Inspiratif, Konstruktif, dan Prosfektif. Jakarta: Prestasi Pustaka.

Ash Shiddieqy (2011), Teungku Muhammad Hasbi. Tafsir Alquranul Majdid Annur. Jakarta: Cakrawala Publishing.

Asnawir dan Usman, Basyiruddin (2001). Media Pembelajaran. Jakarta: Ciputat Pers.

Ayoti, Caroline and Moses Wesang'ula Poipoi (2013). "Challenges Facing Teachers In Preparation And Utilization Of Instructional Media In Teaching Kiswahili In Selected Secondary Schools In Kenya”. International Journal of Advanced Research (2013), Volume 1, Issue 3, 201-207. ISSN NO 2320-5407.

Basrowi (2008). Memahami Penelitian Kualitatif. Jakarta: Rineka Cipta.

Choongjae. Park, Myonghwa (2014).

"Development and Evaluation of a Computerized Multimedia Approach to Educate Older Adults about Safe Medication". Jurnal International: Asian Nursing Research 8 (2014). Pg. 193-200. 
Collins, Janet. Hammond, Michael and Jerry Wellington (1997). Teaching and Learnig with Multimedia. London and New York: Routledge.

Daryanto (2010). Media Pembelajaran (Peranannya Sangat Penting dalam Mencapai Tujuan Pembelajaran). Yogyakarta: Gava Media.

Emzir (2007). Metodolodi Penelitian Pendidikan, Edisi Revisi. Jakarta: Rajawali Press.

Firguson, Melanie. Brandret, Marian.

William Brassingthon \& Heather Wharrad. (2015). "Information

Retention and Overload in First-Time Hearing Aid Users: An Interactive Multimedia Educational Solution”. Journal International Research Forum American Journal of Audiology (AJA). Vol. 24. 329-332. September 2015.

Hanafi, Abdul Halim (2014). Metodologi Penelitian Kependidikan. Batusangkar: IAIN Batusangkar Press.

Harjanto (2008). Perencanaan Pengajaran. Jakarta: Rineka Cipta.

Hasil Ujian Tengah Semester Siswa kelas VIII di Perguruan Thawalib Putri Padang Panjang. Di peroleh dari Guru SKI pada hari Selasa/ 8 Januari 2016.

134 || Jurnal al-Fikrah, Vol. IV, No. 1, Januari-Juni 2016
Hasil wawancara peneliti dengan guru mata pelajaran SKI di Perguruan Thawalib Putri Padang Panjang. Hari Senin, 09 November 2015.

Hasil wawancara Peneliti dengan siswa kelas VIII di Perguruan Thawalib Putri Padang Panjang. Pada hari Kamis, 26 November 2015.

Ilyas, Asnelly (2006). Evaluasi Pendidikan. Batusangkar: IAIN Batusangkar Press. James, Liju \& Shivakumara (2015). “A Study to Assess the Impact of Multimedia Usage on Behavioural Patterns of the Pre-University College Students in Selected Colleges at Mangalore”. Jurnal International: Asian J. Nursing Edu. and Research 5(2): April- June 2015. ISSN 2231-1149 (Print). 2349-2996 (Online).

Kristiawan, Muhammad (2014). Pengembangan Perangkat Lunak Model Peningkatan Kompetensi Guru dalam Pemanfaatan Komputer sebagai Alat Bantu Pembelajaran. Disertasi Program Studi Ilmu Pendidikan Program doktor Program Pascasarjana Universitas Negeri Padang.

Lee, William W. and Owens Diana L (2014). Multimedia-Based Instructinal Design, San Francisco, USA : Pfeiffer, an imprint of Wiley. 
Lefrancois, Guy R (1994). Psyhology for Teaching. Belmont, California: Wadsworth Publishing Company. Eighth Edition.

Mahsunah (2011). Pengembangan Metode Kisah Berbasis Multimedia dalam Pembelajaran Sejarah Kebudayaan Islam di Mts Negeri Jepon Blora”. Tesis: Program Pascasarjana UIN Sunan Kalijaga. Yogyakarta.

Musthafa, Azlina. Najid, Norazura Ezuana Mohd. Siti Salwa Md. Sawari Students' "Perceptions and Attitudes towards the effectiveness of Prezi Uses in learning Islamic Subject". Institute of Education International Islamic University Malaysia.

Ramshaw, Young. Garsha, Shuler. Wilson Write. Duncan and Mason. (2001). "The Role of Multimedia Interactive Programs In Training For laparoscopic procedures". International Journal: Surgical Endoscopy Ultrason and Interventional Techniques. Verlac Newyork In (2001) 15: 21-27. DOI: $10.1007 / s 00464000319$.

Riduwan, M.B.A, Belajar Mudah Penelitian Untuk Guru-Karyawan dan Penelitian Pemula (Bandung: Alfabeta, 2005).

Setyosari, Punaji (2015). Metode Penelitian Pendidikan dan Pengembangan. Jakarta: Prenadamedia Group.
Smaldino, Sharon E. Russel, James D. Robert Heinich. Michael Molenda. Instructional Technology and Media for Learning. Columbus, Ohio: Upper Saddle River, New Jersey, tt. Eight Edition. Hlm. 9. Tersedia: https:// navelmangelep.files.wordpress.com/2013/08/ instructional-technology-and-media forlearning-8th-ed.pdf. Di akses pada hari Rabu, 16 Maret 2016.

Sudjana, Nana \& Rivai (2010). Media Pembelajaran. Bandung: Sinar Baru Algesindo.

Sugiyono (2007). Metode Penelitian Pendidikan Pendekatan Kuantitatif, Kualitatif, dan $R$ \& D. Bandung: Alfabeta.

Susilanan, Rudi \& Riyana, Cepi (2007). Media Pembelajaran (Hakikat, Pengembangan, Pemantapan, Penilaian). Bandung: Wacana Prima.

Thomas, Chaty Newman (The University of Missouri ) and Rhiet, Herbeht J. (The University Texas at Austin) (2011), "A Research Sinthesis of the Literatur Multimedia Achored Intruction in Preservise Teacher Education”. Journal Special of Education Technology: 2011, Volum. 26, Number. 2. ProQuest Nursing \& Allied Health Source. Pg. 1. 
Trianto (2009). Mendesain Model Pembelajaran Inovatif-Progresif (Konsep Landasan, dan Implementasinya pada Kurikulum Tingkat Satuan Pandidikan (KTSP)). Jakarta: Kencana.

Yeh, Mei-Ling. Chen, Hsing-Hsia (2012). "Yu-Chu Chung di Taiwan. One year study on the integrative intervention of acupressure and interactive multimedia for visual health in school children". Journal home page: www.elsevierhealth.com/ journals/ctim. Complementary Therapies in Medicine (2012) 20, 385-392.
Ziden, Azidah Abu. Rahman, Muhammad Faizal Abdul. "The Effectiveness of Web-Based Multimedia Applications Simulation in Teaching and Learning. International Journal of Instruction July 2013. Vol.6, No.2. e-ISSN: 1308-1470.

Zuhairini (1986). Sejarah Pendidikan Islam. Jakarta: Direktorat Jendral Pembinaan Kelembagaan Agama Islam. 